\title{
Review
}

\section{Arthritis and pain Future targets to control osteoarthritis pain} Andy Dray ${ }^{1}$ and Simon J Read ${ }^{2}$

\author{
${ }^{1}$ AstraZeneca R\&D Montreal, Frederick Banting St, Montreal H4S 1Z9, Canada \\ ${ }^{2}$ AstraZeneca R\&D, Mereside, Alderley Park, Macclesfield, Cheshire SK10 4TG, UK
}

Corresponding author: Andy Dray, Andy.Dray@astrazeneca.com

Published: 30 May 2007

This article is online at http://arthritis-research.com/content/9/3/212

(c) 2007 BioMed Central Ltd
Arthritis Research \& Therapy 2007, 9:212 (doi:10.1186/ar2178)

\begin{abstract}
Clinical presentation of osteoarthritis (OA) is dominated by pain during joint use and at rest. OA pain is caused by aberrant functioning of a pathologically altered nervous system with key mechanistic drivers from peripheral nerves and central pain pathways. This review focuses on symptomatic pain therapy exemplified by molecular targets that alter sensitization and hyperexcitability of the nervous system, for example, opioids and cannabinoids. We highlight opportunities for targeting inflammatory mediators and their key receptors (for example, prostanoids, kinins, cytokines and chemokines), ion channels (for example, NaV1.8, NaV1.7 and CaV2.2) and neurotrophins (for example, nerve growth factor), noting evidence that relates to their participation in $\mathrm{OA}$ etiology and treatment. Future neurological treatments of pain appear optimistic but will require the systematic evaluation of emerging opportunities.
\end{abstract}

\section{Introduction}

Osteoarthritis (OA) is recognized by degeneration of articular cartilage, synovitis, remodeling of subchondral bone and atrophy/weakness of joint muscles. Clinical presentation is dominated by pain during joint use and often at rest. There are circadian variations in pain severity in both knee and hand $\mathrm{OA}$, with pain worsening in the evening $[1,2]$. Pain frequency and intensity has been related to obesity, helplessness and education as well as a significant co-morbid association with anxiety and depression [3].

There are major distinctions between physiological and pathophysiological (chronic) pain. Physiological pain is a necessary defense mechanism, related directly to the degrees of existing or imminent tissue damage, and is essential for survival. On the other hand, chronic pain serves no defensive or helpful function, since neither the intensity nor quality of chronic pain is related to the degree of tissue damage and may persist long after the resolution of any initial insult. Chronic pain (nociceptive or neuropathic) is now recognized as a manifestation of an aberrant functioning of a pathologically altered nervous system. Pain therapy, and the emerging pharmacology, is seen in terms of symptomatic treatment (through modulation of aberrant function, that is, neural excitability) and disease modification (through neural restoration of physiological pain processing). This is the context in which we will develop new therapies and will be the focus of this review. However, this does not deny that disease modifying approaches, for example, to resolve joint or cartilage degeneration, may also impact on OA pain.

Pain in OA, like other chronic pain conditions, is a complex integration of sensory, affective and cognitive processes that involves a number of abnormal cellular mechanisms at both peripheral (joints) and central (spinal and supraspinal) levels of the nervous system. The relative contribution of these processes in the OA population appears to be strongly segmented. Intra-articular anesthetic studies in hip and knee OA support a peripheral drive to pain in approximately $60 \%$ to $80 \%$ of patients, depending on the affected joint $[3,4]$. In some individuals, however, central mechanisms, for example, dysfunction of descending inhibitory control [5] or altered

ATF-3 = activating transcription factor-3; AMPA $=\alpha$-amino-3-hydroxy-5-methylisoxazole-4-proprionate; ASIC = acid-sensing ion channel; BDNF = brain-derived neurotrophic factor; BoNT = botulinum toxin; $\mathrm{CCL}=\mathrm{CC}$ chemokine ligand; $\mathrm{CGRP}=$ calcitonin gene-related peptide; $\mathrm{CNS}=\mathrm{central}$ nervous system; COX = cyclo-oxygenase; cPGES = cytosolic PGE synthase; $\mathrm{DOR}=$ delta opioid receptor; $\mathrm{DRG}=$ dorsal root ganglion; $\mathrm{EP}=\mathrm{E}$ prostanoid receptor; GFR = glial cell line-derived neurotrophic factor receptor; GDNF = glial-derived neurotrophic factor; iGluR $=$ ionotropic glutamate receptor; IL = interleukin; mGluR = metabotropic glutamate receptor; MPEP = 2-methyl-6[phenylethynyl]-pyridine; mPGES = membrane or microsomal PGE synthase; NGF = nerve growth factor; NMDA = N-methyl-D-aspartate; NSAIDs = non-steroidal anti-inflammatory drugs; NT = neurotrophin; $\mathrm{OA}=$ osteoarthritis; $\mathrm{P} 2 \mathrm{X}=$ purinergic $2 \mathrm{X}$ ionotropic receptor; $\mathrm{PG}=$ prostaglandin; $\mathrm{PGES}=\mathrm{PGE}$ synthase; $\mathrm{TNF}=$ tumor necrosis factor; TNP-ATP = 2',3'-O-(2,4,6-trinitrophenyl)-adenosine triphosphate; Trk = tyrosine kinase; TRP $=$ transient receptor potential; TRPV $=$ TRP vanilloid; TTX = tetrodotoxin; UV = ultra-violet; VAS = visual analogue scale. 


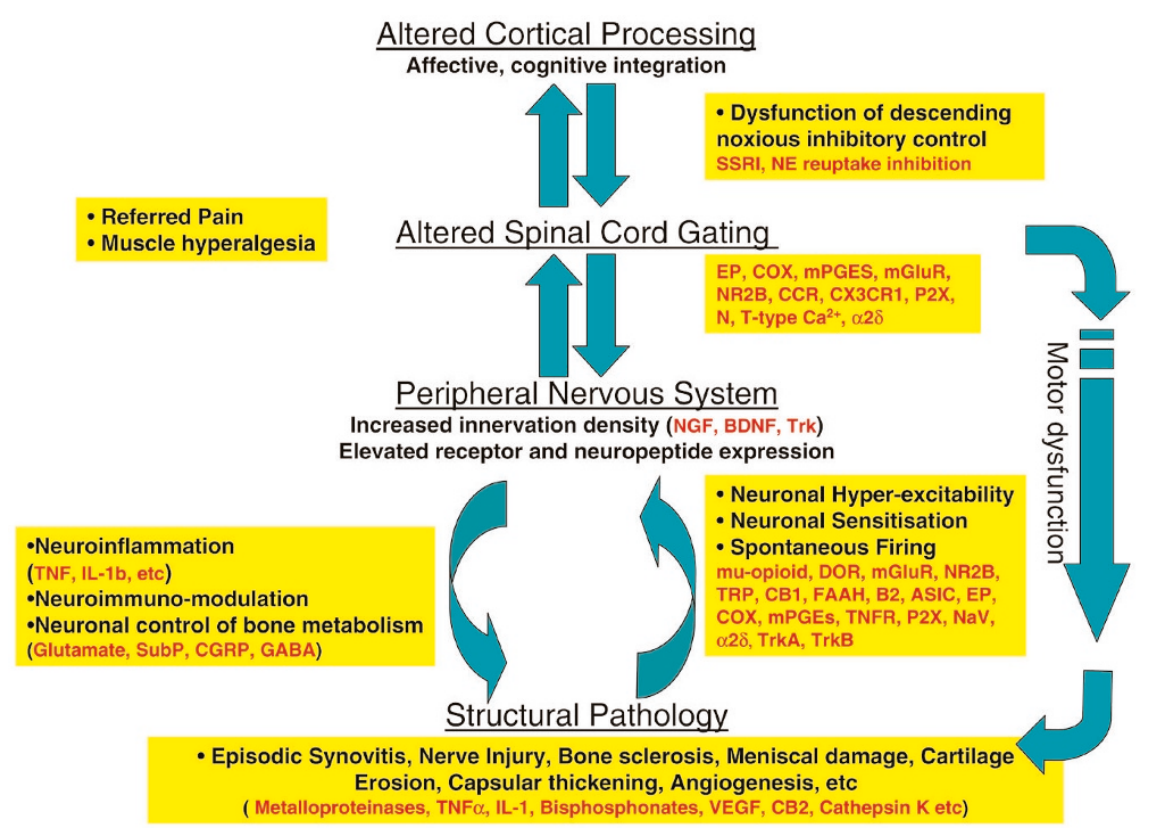

Key elements of osteoarthritis (OA) pain pathophysiology and examples of pharmacological intervention points. Observations of pain resolution following intra-articular local anesthetic and following joint replacement would implicate a peripheral drive in the majority of OA patients. In the periphery, the interaction between structural pathology, and the immune and nervous systems perpetuate the pain experience. Over time, as structural pathology develops, the principle algogenic mechanisms and mediators will change. Furthermore, dysfunction in central processing of information at the spinal and cortical levels has also been observed in OA patients, affecting both sensory and motor systems. This, in combination with altered affective and cognitive functions, may underpin the pain experience in other patient subsets. ASIC, acid-sensing ion channel; BDNF, brain-derived neurotrophic factor; $\mathrm{CB}$, cannabinoid receptor; $\mathrm{CCR}$, chemokine receptor; CGRP, calcitonin gene-related peptide; COX, cyclooxygenase; DOR, delta opioid receptor; EP, E prostanoid receptor; FAAH, fatty acid amide hydrolysis; GABA, gamma-amino butyric acid; IL, interleukin; mGluR, metabotropic glutamate receptor; mPGES, membrane or microsomal PGE synthase; $\mathrm{N}$-type $\mathrm{Ca}^{2+}$, neuronal-type calcium channels; NE, noradrenaline; NGF, nerve growth factor; NR2B, -N-methyl-D-aspartate receptor $2 \mathrm{~B}$ subunit; $\mathrm{P} 2 \mathrm{X}$, purinergic $2 \mathrm{X}$ ionotropic receptor; SSRI, selective serotonin reuptake inhibitor; SubP, substance P; T-type $\mathrm{Ca}^{2+}$, transient type $\mathrm{Ca}^{2+}$ channels; TNF, tumor necrosis factor; TNFR, tumor necrosis factor receptor; Trk, tyrosine kinase; TRP, transient receptor potential; VEGF, vascular epidermal growth factor.

cortical processing of noxious information, may play a greater role [6].

With such patient heterogeneity, identifying pharmacological targets of the future is fraught with issues. Biomarker development and patient stratification will need to be progressed in parallel to ensure 'tailor-made treatment'. More narrow titration of preclinical activities, for example, animal models, in vitro assays and so on, to specific patient subsets may also be required to improve predictability in humans. Nevertheless, rational mechanistic approaches can be taken. Alterations in the physiology of sensory pathways, such as sensitization (reduced threshold for stimulation), hyperexcitability (amplification or prolongation of nerve discharge) or spontaneous nerve activity, can be associated with specific molecular changes.

In this review we have selected examples of emerging pharmacology for the treatment of OA pain (Figure 1). Where appropriate, examples of inflammatory and neuropathic pain pharmacology have been highlighted, since there is continuing discussion as to whether components of osteoarthritic pain are also neuropathic (see [7] for a review). Ultimately, in any patient, multiple algogenic mechanisms may underpin the pain experience. Combinations of pharmacological approaches may, therefore, be a requirement for effective pain management. However, 'chasing' efficacy with combinations will need to be balanced against the cumulative safety burden of treatments. Indeed, OA patients (particularly the elderly) may be willing to forgo efficacy in favor of lower adverse event risk [8].

\section{Target classes}

\section{Opioids and their receptors}

Opioids have been a mainstay of chronic pain therapy for many years. They act at peripheral, spinal, and supraspinal sites through a variety of opioid receptors (mu-, delta-, and kappa-opioid receptors) [9]. Opioids used in the clinic, such as morphine, act via mu-opioid receptors to cause a variety of well documented side effects, including sedation, dysphoria, respiratory depression and constipation. However, opioid receptor activation in the periphery, which directly hyper- 
polarizes sensory neurones and attenuates nerve hyperexcitability caused by inflammation or injury [10,11], raises the possibility of therapy with minimal central nervous system (CNS) side effects. In keeping with this, limited clinical trials of intra-articular delivery of morphine in OA support the concept of peripherally restricted opiate analgesia [12]. Furthermore, novel mu-opioid ligands, such as [8-(3,3diphenyl-propyl)-4-oxo-1-phenyl-1,3,8-triaza spiro [4.5]dec-3yl]-acetic acid (DiPOA) and the antidiarrheal drug loperamide, which also do not penetrate the blood brain barrier, have shown efficacy in a number of post operative, inflammatory and bone cancer pain models $[13,14]$.

Delta-opioid receptor (DOR) agonists have the potential for analgesic efficacy without the confounding side effects of other opioid receptor therapies (see [15] for a review). Thus, analgesia has been shown in primate and non-primate pain models with a number of DOR ligands, for example, [D-Pen2,D-Pen5] enkephalin, SNC80 and AM-390. However, DOR efficacy depends on the pain stimulus, the type of injury and the influence of the local neurochemical environment. Thus, delta ligands have low analgesic efficacy in acute pain models but show robust analgesia efficacy in a variety of chronic pain conditions accompanied by inflammation $[16,17]$. This can be explained by stimulus-dependent trafficking of DOR from the cytoplasm to nerve membranes in CNS neurons [16]. There is little clinical development of DOR agonists for analgesia, although ADL 5859 [17] is reported to be in clinical phase 1 for analgesia.

\section{Kinins and their receptors}

Bradykinin is an important mediator of inflammatory pain causing nociceptor activation and sensitization via B2 receptors [18]. The abundant metabolite of bradykinin, des-Arg9-bradykinin (kallidin), activates B1 receptors, which occur in low abundance, in the periphery and CNS [19-21].

B2 receptors undergo desensitization following prolonged kinin exposure, whereas B1 receptors do not desensitize rapidly and are dramatically up-regulated in many tissues following injury [22-25] or exposure to IL-1 $\beta$ or the neurotrophin glial-derived neurotrophic factor (GDNF) [23,26]. Importantly, kinins cause a cascade of secondary changes, including prostanoid and nitric oxide production, phosphorylation of signaling proteins such as PKC, and the sensitization of sensory transducers such as the transient receptor potential vanilloid (TRPV) 1 receptor [27]. These events are linked with heat and mechanical hyperalgesia $[28,29]$. In keeping with this, B2 antagonists (for example, Icatibant and bradyzide) and a B1 antagonist (des-Arg10 HOE-140; SSR240612) produce robust anti-hyperalgesic effects in models of nerve injury-induced pain [30-33]. Importantly, intra-articular administration of Icatibant (HOE 140) in OA patients was shown to reduce pain intensity at rest and during activity [33].

\section{Cannabinoids and their receptors}

Two cannabinoid receptors, CB1 and CB2, are associated with pain modulation (reviewed in [35]). CB1 receptors are widely distributed in the CNS and peripheral sensory neurons while CB2 receptors have been found in peripheral tissues, including tissues of the immune system and keratinocytes, with limited expression in sensory and CNS cells [36]. More recently, constitutive expression of both CB1 and CB2 receptors have been isolated on chondrocytes and implicated in a potential disease modifying role in OA [37]. Several fatty acids, for example, anandamide, 2-arachidonylglycerol, and palmitoylethanolamide, have been identified as the endogenous ligands for these receptors while specific antagonists, such as SR141716A and SR147778 for CB1 and SR144428 for CB2, have been used to characterize receptor functions.

CB1 receptors attenuate pain by reducing peripheral nerve excitability and through inhibition of sensory transmitter release [38]. In the CNS, brain stem structures such as the periaqueductal grey appear to be important for stressinduced release of endocannabinoids, and CB1-induced analgesia may involve activation of descending pathways that inhibit spinal excitability $[39,40]$.

Several clinical studies have shown that many cannabinoids, such as delta(9)-tetrahydrocannabinol, that reduce pain by a CNS action also produce adverse effects, such as euphoria, dizziness and sedation [41]. Targeting peripheral cannabinoid receptors can reduce CNS side effects. Thus, localized administration of $\mathrm{HU} 210$ or oral administration of CB1 agonists with limited CNS availability, such as CT-3 (ajulemic acid), produced analgesia both in pain models $[42,43]$ and in the clinic at a dose that causes minimal CNS side effects [44].

CB2 agonists (for example, HU-308, HU-210, CP55940, AM1241 and GW405833) also modulate acute and chronic pain [45-47] while JWH-133 also shows anti-inflammatory activity [48]. It is unclear how these effects are produced since few CB2 receptors are found in the CNS or on sensory neurons [49]. However, CB1 like side effects (sedation, catalepsy, motor impairments) have not been seen with CB2 selective compounds.

Another ongoing approach for pain reduction is to harness the endogenous cannabinoid systems by targeting fatty acid amide hydrolysis, the major degradation pathway for endogenous cannabinoids [50]. Thus, in mice lacking this enzyme [51], or after treatment of naïve mice with a novel fatty acid amide hydrolysis inhibitor, such as URB597 and OL135, there is significantly elevated brain anandamide and increased pain threshold in pain models [52,53]. Finally, several reports have indicated analgesic synergy between mu-opioid and CB receptors. Thus, combinations of these agonists have been shown to provide pain reduction with minimal side effects in acute pain models [54]. However, it is 
still unclear whether such synergy can be exploited in chronic pain treatment such as OA.

\section{Prostanoids and receptors}

A variety of prostanoid cyclo-oxygenase (COX) enzyme products (prostaglandin (PG)E2, PGD2, PGF2 $\alpha$, thromboxane, PGI2) are made during inflammation, but PGE2 is considered to be the major contributor to inflammatory pain. Thus, blocking the major synthetic enzymes COX-1 and COX-2 or inhibition of prostanoid receptors continue to be important approaches for reducing inflammatory pain. PGE2 exerts its effects via a variety of $E$ prostanoid (EP) receptors (EP1, EP2, EP3, EP4), which are present in both peripheral sensory neurones and the spinal cord. Activation of these receptors produces a complexity of effects, ranging from calcium influx to cAMP activation or inhibition. Sensitization of nociceptors by PGE2 is caused by the CAMP-mediated enhancement of sodium currents via ion channel phosphorylation $[55,56]$. However, in the spinal cord, prostaglandin-induced hyperexcitability was enhanced by EP1 receptors but reduced by an EP3 $\alpha$ agonist (ONO-AE248), suggesting further complexity in the prostanoid regulation of pain [57].

In addition to their important roles in the periphery, COXs are also present in the CNS. Important for pain is the increased spinal cord expression of COX-1 (glia) and COX-2 (ventral horn cells) caused by inflammation, peripheral nerve injury or cytokines. In keeping with this, several non-steroidal antiinflammatory drugs (NSAIDs) have been shown to reduce inflammatory hyperalgesia via inhibition of spinal COX activity [58]. Several mechanisms have been proposed, including EP1 receptor activation and spinal release of glutamate as well as loss of spinal glycine receptor mediated inhibition [59]. Recently, COX-3 has been identified as a splice variant of COX-1 [60] and several NSAIDs (acetaminophen, diclofenac, phenacetin) show low efficacy but some degree of selectivity for COX-3. However, COX-3 has low enzymic capability and its distribution and low abundance in the CNS and periphery does not make this a compelling target for analgesia.

Since the 1990s, COX-2 selectivity has been associated with cardiovascular concerns following observations of reduction in anti-thrombotic prostacylin metabolites but not prothrombotic thromboxane A2 in urine. Large scale, controlled clinical trials for COX-2 inhibitors (VIGOR, CLASS, TARGET) comparing efficacy and safety of rofecoxib, celecoxib and lumiracoxib with traditional NSAIDs have confirmed an increased risk of serious cardiovascular events compared to placebo. Many key questions remain unanswered concerning the mechanism of cardiovascular risk of selective COX-2 inhibitors (see [61] for a review). Despite this uncertainty, development of COX-2 selective inhibitors still continues (for example, GW406381), reflecting the attraction of this pathway and the requirement for newer drugs with improved overall safety profiles.
An alternative route of PGE2 inhibition is via the blockade of PGE synthase (PGES), a major route of conversion of prostaglandin $\mathrm{H} 2$ to PGE2. Two iso-forms of the enzyme have been identified, membrane or microsomal associated (mPGES-1) and cytosolic (cPGES/p23), which are linked with COX-2 and COX-1 dependent PGE2 production, respectively $[62,63]$. Both isoforms are up-regulated by inflammatory mediators, and gene deletion studies in mice indicate an important role for mPGES in acute and chronic inflammation and inflammatory pain [64]. Additionally, inhibition of mPGES is thought to be associated with lower cardiovascular risk since PGI2 production would not be affected.

\section{Cytokines, chemokines and their receptors}

Inflammatory stimuli initiate a cascade of events, including the production of tumor necrosis factor (TNF) $\alpha$, ILs, chemokines, nerve growth factor (NGF), sympathetic amines, leukotrienes and PGs, with a complex impact on pain production. Cytokines induce hyperalgesia by a number of direct and indirect actions. Thus, IL1 $\beta$ activates nociceptors directly via intracellular kinase activation, but it may also cause indirect nociceptor sensitization via the production of kinins and prostanoids [65]. TNF $\alpha$ also activates sensory neurones directly via the receptors TNFR1 and TNFR2 and initiates a cascade of inflammatory reactions through the production of IL1, IL6 and IL8 $[66,67]$. It is significant that direct TNF $\alpha$ application in the periphery induces neuropathic pain behavior that is blocked by ibuprofen and celecoxib [68], while nerve ligation causes increased TNF $\alpha$ in damaged as well as adjacent undamaged axons [69]. Interestingly, anti-TNF $\alpha$ treatment with the TNF antibody adalimumab produced a prolonged reduction of pain symptoms in OA [70]. These are encouraging preliminary data but will require further support.

Chemokines are important peripheral and central regulators of chronic inflammation, typically orchestrating leucocyte migration. However, recent studies implicate chemokine receptors in brain development, neurodegenerative conditions and synapse activity. Receptors have been detected throughout the CNS in the macrophage-'like' microglial cells, astrocytes, oligodendrocytes and neurons [71]. Receptors have been co-localized with isolectin B4 and substance P primary afferent neurons and dorsal root ganglion cultures respond to chemokines with transient $\mathrm{Ca}^{2+}$ influx [72]. Chemokines can contribute directly to hyperalgesia through G-protein coupled sensitization of ligand gated channels, for example, TRPV1, heterologous desensitization of opioid receptors and sensitization of sensory neurones [72,73]. For example, pro-inflammatory cytokines, such as CC chemokine ligand 2 (CCL2) and CCL3 (MIP-1a), sensitize TRPV1 to capsaicin via removal of an intracellular phospholipid inhibitor [72]. Furthermore, CCL2, CCL3 (MIP-1a), CCL5 and CXC chemokine ligand 8 also desensitize mu-opioid receptors. Therefore, the phasic synovitis that accompanies OA may serve as a priming event for subsequent hyperalgesia, mediated in part by chemokine and cytokine priming of 
sensory afferents, or desensitization of the endogenous opioid system.

\section{Adrenergic receptors}

Several chronic pain disorders termed 'sympathetically maintained pain' have highlighted the importance of the release of sympathetic transmitters (epinephrine or norepinephrine) from sympathetic varicosities and the involvement of adrenergic receptors in pain etiology. The joint capsule, synovium and bone are richly innervated by sympathetic postganglionic neurons [74]. These regulate vascular tone and permeability, bone homeostasis and, during inflammation, sensitizing of afferent sensory pathways. In rheumatoid arthritis, sympathetic innervation is reduced, probably by increased release of sympathetic nerve repellents such as semaphorins, although no such denervation is observed in $\mathrm{OA}$ [75]. Interactions between sympathetic and afferent peripheral neurons may take place at several sites. NGF may play an important role in linking sympathetic and C-fibre innervation as sympathetic activation stimulates NGF secretion from vascular smooth muscle [76]. Other pain conditions have demonstrated sympathetic/sensory coupling at the level of the dorsal root ganglion [77] and at the peripheral sites of injury (for example, neuroma) [78].

Studies have also shown the expression of $\alpha-1$ and $\alpha-2$ adrenergic receptors on sensory neurons or on postganglionic sympathetic terminals after nerve injuries $[79,80]$. Under these conditions sensory neurones can be directly activated by the endogenous release of sympathetic transmitters (via $\alpha-1$ receptors) or in the clinic by intradermal injection of norepinephrine [81].

Clonidine and other $\alpha-2$ agonists such as dexmedetomidine have also been used systemically to inhibit sensory transmission in the spinal cord by block of pre- and postsynaptic membrane excitability and intra-articularly following joint replacement. Unfortunately, sedation and hypotension are major target-related systemic side effects of these compounds. Great efforts have been made to identify ligands with improved $\alpha-2$ receptor subtype selectivity, to avoid side effects, but thus far this has not been particularly successful.

\section{Glutamate regulation and glutamate receptors}

In OA, synovial fluid levels of glutamate and aspartate are significantly elevated above controls [82]. Glutamate acts through a variety of receptor-coupled, ligand-gated ion channels, including $\alpha$-amino-3-hydroxy-5-methylisoxazole-4proprionate (AMPA)/kinate receptors, ionotropic glutamate receptors (iGluRs) and G-protein coupled metabotropic glutamate receptors (mGluRs). Injections of glutamate or metabolically stable receptor-selective agonists such as NMDA, AMPA, and kainate cause a pro-nociceptive response upon thermal and mechanical stimulation, while application of iGluR and mGluR antagonists attenuate pain in acute models (see $[83,84]$ for reviews). Glutamate may also have a disease-modifying role, with receptors found on non-neuronal cells, that is osteoblasts, osteoclasts, and chondrocytes, mediating bone remodeling and cartilage mechano-transduction, respectively $[85,86]$.

NMDA antagonists show robust attenuation of pain behaviors but also induce a number of side effects (sedation, confusion, motor incoordination) and thus have insufficient therapeutic margin. There has been a refocus on more specific NMDAreceptor subtype blockers (NR1 and NR2) directed towards the strychnine-insensitive glycine ${ }_{B}$ modulatory site to avoid side effects. This site modulates the NMDA channel only during the sustained stimulation of the receptor, which is considered to occur during chronic pain. Selective NR1-Gly antagonists have been claimed to reduce pain with reduced side effects $[87,88]$. However, clinical experience has not confirmed this. GV196771 did not show efficacy against clinical pain, possible due to inadequate penetration into the CNS [89].

Alternative initiatives have targeted other NMDA receptor subtypes, such as the NR2B receptor, which has a specific distribution in sensory pathways. Blockade of this receptor has also been claimed to produce anti-nociception (ifenprodil, traxoprodil (CP-101,606)) with reduced side effects [90]. To date, traxoprodil has advanced into phase I safety and efficacy study for acute ischemic stroke.

The mGluRs, particularly mGluR1 and mGluR5, have been reported to play a key role in sustaining heightened central excitability in chronic pain with minimal involvement in acute nociception. Thus, spinal administration of selective agonists such as dihydroxy phenyl glycine produced allodynia, while mGluR5 was shown to be significantly over-expressed in some, but not all, chronic pain models [91]. Peripheral mGluR5 receptors have also been claimed to modulate pain. Thus, local administrations of mGluR5 antagonists 2-methyl6[phenylethynyl]-pyridine (MPEP) and SIB1757 have been effective in reducing pain behavior, suggesting a potential use in pain therapy [92,93].

Metabotropic group II receptors (mGluR2 and mGluR3) also modulate pain transmission. mGluR2 is located in sensory neurones and presynaptic nerve terminals whereas mGluR3 is found all over the brain. mGluR3 can be selectively increased in the spinal dorsal horn neurones after peripheral UV injury [94]. mGluR2/3 receptor activation appears necessary to reduce nerve terminal excitability and to modulate pain transmission since treatment with the agonist L-acetyl carnitine reduced inflammatory hyperalgesia and mechanical allodynia and increased the expression of mGluR2/3. The effects of L-acetyl carnitine were attenuated by LY379268, an mGluR2/3 antagonist [95].

\section{Ion channels}

A variety of ligand and membrane voltage-regulated ionchannels is involved in pain modulation and these have been 
targeted for pain control. The mammalian TRP channel represents a large receptor family, subdivided into six subfamilies: TRPA, TRPC, TRPM, TRPP, TRPV, and mucolipin. Many TRP channels are localized to sensory neurones and play a major role in temperature and mechanical transduction.

TRPV1 is a non-selective cation channel, gated by capsaicin, noxious heat $\left(>45^{\circ} \mathrm{C}\right)$, acidic $\mathrm{pH}(<5.3)$, and regulated by a variety of inflammatory agents, including protons, bradykinin, ATP, PGE2, 12-lipoxygenase products, protease-activated receptor-2, anandamide, CCL3 and NGF. Sensitization of TRPV1 involves a variety of pathways that regulate receptor phosphorylation [96]. Analgesia approaches in OA have used capsaicin preparations or capsaicin-like agonists to induce TRPV1 desensitization or reversible sensory nerve terminal degeneration caused by prolonged cation influx into the nerve, osmotic damage and metabolic collapse [97]. In a randomized study of intra-articular injections of placebo or capsaicin (ALGRX 4975) prior to knee replacement, ALGRX 4975 was found to decrease visual analogue scales (VAS) scores without effecting proprioreception or joint histopathology [98]. Currently, there is a focus on TRPV1 channel blockers or selective TRPV1 receptor antagonists [99]. Supporting these approaches, competitive (AMG-9810) [100] and non-competitive (DD161515) [99] TRPV1 antagonists block chemical and thermal pain sensitivity, heralding the emergence of a novel therapy. Indeed, recent studies in volunteers have shown that oral SB705498 attenuated capsaicin and ultra-violet (UV)-induced pain and hyperalgesia [101]. Other TRP channels (TRPV3, TRPV4, TRPA1) have also been suggested to be involved in pain transduction. Thus, TRPA1 (ANKTM1) is co-localized with TRPV1 and is activated by capsaicin and mustard oil but can also be sensitized by inflammatory mediators, including bradykinin, known to be significantly elevated in osteoarthritic synovial fluid, to produce cold-induced burning pain [102]. In addition, TRPV1 can oligomerize with other TRP family members, including TRPV3. The latter is found in keratinocytes and appears to be upregulated in inflammatory pain conditions. So far there are few reliable chemical tools to help characterize the functions of these TRP receptors and support their value as analgesia targets.

\section{Purinergic receptor-regulated channels}

The unique localization of the purinergic $2 \mathrm{X}$ ionotropic (P2X)3 receptor to small sensory fibres has highlighted its importance in pain. Large amounts of the endogenous ligand ATP are released after tissue injury and during inflammatory injuries while both ATP and a stable analogue, $\alpha, \beta$-methyl ATP, induce pain and are pronociceptive when administered intradermally in volunteers [103].

In chronic inflammatory pain, P2X3-mediated excitability is enhanced while reduction of $\mathrm{P} 2 \mathrm{X} 3$ receptors by antisense oligonucleotide administration reduces inflammatory hyperalgesia as well as that evoked by $\alpha, \beta$-methyl ATP [104]. In keeping with this, several antagonists, including $2^{\prime}, 3^{\prime}-\mathrm{O}-(2,4,6-$ trinitrophenyl)-adenosine triphosphate (TNP-ATP), pyridoxalphosphate-6-azophenyl-2', $4^{\prime}$-disulfonic acid, and suramin, reduce pain behavior. More selective, and drug like, antagonists, such as A-3174919, reduced pain in a number of acute and chronic pain models, supporting the possibility for future analgesia therapy of nociceptive pain such as OA [105].

It should be noted that several other purinergic receptor subtypes, including P2X4 and P2X7, have also been suggested to modulate pain through altered central excitability and the release of neuroglial-cell products [106-108]. Thus, activated microglia, astrocytes and satellite cells release a variety of inflammatory mediators, including IL1 $\beta$, TNF $\alpha$, prostanoids and nitric oxide upon ATP stimulation. Indeed, increased expression of P2X4 has been shown to occur in spinal microglia after peripheral nerve lesions and this was related to painful mechanical allodynia. This behavior was blocked by spinal administrations of the selective P2X4 antagonist TNP-ATP [106]. Remarkably, spinal administration of activated microglia reproduced TNPATP sensitive mechanical allodynia in naïve animals.

Increased P2X7 expression has been found in peripheral macrophages following inflammation but this receptor is also expressed in spinal neurones and microglia following peripheral nerve injury [107]. In keeping with an important role in chronic pain, both microglia and P2X7 receptors are up-regulated in human chronic pain patients [108] while deletion of the $\mathrm{P} 2 \mathrm{X} 7$ receptor gene produced a complete absence of mechanical and thermal pain in mice [108].

It is worth noting that other nucleotide-gated ion channels have also been shown to be important for regulating peripheral excitability. Thus, the $\mathrm{Na} / \mathrm{K}$ re-polarizing 'pacemaker current', Ih, which is activated during membrane hyperpolarization, is important for generation of rhythmic and spontaneous action potentials in sensory neurons. Ih currents are controlled by cyclic nucleotides (cAMP and cGMP) via a family of hyperpolarization-activated, cyclic nucleotide-gated (HCN1-4) ion channels. These have been found to be differentially expressed and redistributed after inflammatory nerve injuries [109,110].

\section{Acid sensing ion channels}

Several arthritidies, including OA, are associated with decreases in local $\mathrm{pH}$ during osteoclastic bone resorption, inflammation and tissue hypoxia [111]. $\mathrm{H}^{+}$ions can directly activate nociceptors via multiple mechanisms, for example, TRPV1 channels as previously discussed, and via acidsensing ion channels (ASICs). ASICs are $\mathrm{Na}^{+}$channels related to the degenerin/epithelial amiloride-sensitive $\mathrm{Na}^{+}$ channel superfamily of cation channels. Several subunits have been identified, with ASIC 1a 1b, ASIC 2a, 2b and ASIC3 expressed in the majority of dorsal root ganglion (DRG) neurons. The relative contribution of TRPV1 and ASICs to $\mathrm{H}^{+}$activation of sensory afferents is only just 
emerging, but data indicate specificity differences for both species and nerve fibre subtypes (Isolectin B4-/+) [112].

A novel blocker (A-317567) of peripheral ASIC 1, 2 and 3 channels has been described [113]. This reduces hyperalgesia in models of inflammatory and post-operative pain, but there have been no reports of therapeutic advances with ASIC inhibitors.

\section{Sodium channels}

Voltage-gated sodium channels are characterized by their primary structure and sensitivity to tetrodotoxin (TTX). A variety of TTX sensitive (NaV1.3, Nav1.7) and TTX insensitive ( NaV 1.8, NaV1.9) channels are involved in regulating sensory neural excitability [114,115]. Changes in the expression, trafficking and redistribution of $\mathrm{NaVs}$ following inflammation or nerve injury are considered to account for the abnormal firing and the generation of ectopic activity in afferent nerves [116]. Mutations of NaV1.7 have been identified as the cause of burning pain in erythromelalgia [117], while inflammation causes the over-expression of NaV 1.7 in animal models and in inflamed human tooth pulp [118]. Interestingly, NaV1.7 over-expression could be prevented by pre-treatment with COX-1 and COX- 2 inhibitors (ibuprofen, NS-398).

The clinical utility of non-selective $\mathrm{Na}$ channel blockade in OA pain has been well established with the experimental use of local anesthetics such as intra-articular levobupivacaine, the active enantiomer of bupivacaine. It is noteworthy that the OA population is stratified in response to intra-articular local anesthetic, indicating a significant central component to the pain in some patients [3]. Systemic and central exposure to local anesthetics has been attempted in other pain paradigms. Intravenous administration has been reported to produce long lasting pain relief in both animal models [119] and intractable neuropathic pain [120]. The major disadvantages of the systemic use of non-selective $\mathrm{Na}$ channel blockers are cardiotoxicity and CNS sedation and confusion, considered to be produced by NaV1.5 and NaV1.2 channel blocking, respectively. Considerable activity is currently focused on discovering novel, selective $\mathrm{Na}$ channel blockers.

An alternative approach to regulate ion channels is to block the trafficking of channels to the nerve membrane. For example, the functioning of $\mathrm{NaV} 1.8$ may be reduced by preventing an association with $\mathrm{p}-11$, an annexin $\mathrm{II}$ related protein that tethers the channel to the nerve membrane [121]. In addition, channel-associated cell surface glycoproteins such as contactin may be involved in concentrating specific channel subtypes, for example, NaV1.8 and NaV1.9 (Isolectin B4+) but not NaV1.6 and NaV1.7 (Isolectin B4-) in DRG nerve membranes, with an associated increased in ionic current density [122]. Although these approaches are attractive, they have not been explored significantly and it is unclear whether they will impact on nerve excitability associated with specific pain etiology.

\section{Calcium channels}

Voltage-gated calcium channels are subdivided into two major categories, low voltage-activated calcium channels (T-type channels) and high voltage-activated. High voltageactivated channels are further subdivided, based on pharmacology and biophysical characteristics, into L-, N-, R-, P-, and Q-types. Several have been shown to be prominently involved in pain regulation [123]. The $\mathrm{N}$-type calcium channel is an important regulator of nerve terminal excitability and neurotransmitter release. N-type channels can be regulated, particularly through GPCR signaling by analgesic drugs such as opioids, with a resultant modulation of sensory transmitter release, for example, substance $P$, calcitonin gene-related peptide (CGRP) and glutamate, at both spinal and peripheral sensory nerve terminals. Channel trafficking may also be affected; for example, activation of the opioid receptor-like receptor by nociceptin causes channel internalization and downregulation of calcium entry [124].

Gene deletion of the $\alpha 2 \delta$ subunit of the N-type channel reduces inflammatory and neuropathic pain $[125,126]$. Moreover, selective blockers such as Ziconotide (SNX-111, Prialt; a synthetic form of omega-conotoxin) and verapamil have been used to characterize channel activity while Ziconitide has been used experimentally and clinically by spinal intrathecal administration for pain relief $[127,128]$. Building on this concept, small molecule channel blockers, with oral availability, are now reported to be undergoing clinical evaluation for analgesia, for example, NMED-160 [128].

Low voltage-activated T channels also appear important for pain transmission and as targets for pain therapy. Thus, they are expressed in superficial laminae of the spinal cord and in dorsal root ganglion neurones [123]. T-channels play a prominent role in regulating spinal excitability and spinal sensitization following repetitive C-fibre stimulation [129]. Moreover, nerve injury-induced hyper-responsiveness was blocked by the T-channel blocker ethosuximide [130], which also attenuated mechanical allodynia in animal models of vincristine and paclitaxel-induced neuropathic pain [131].

Finally, high voltage-activated channels are composed of four subunits, an $\alpha 1$ subunit and auxiliary subunits $\alpha 2 \delta, \beta$, and $\gamma$. There are four human $\alpha 2 \delta$ genes described, $\alpha 2 \delta 1-4$, which associate into different subsets of channels and have different tissue distributions. Pregabalin and gabapentin are inhibitors of $\alpha 2 \delta 1$ and $\alpha 2 \delta 2$. These drugs act as presynaptic inhibitors of the release of excitatory neurotransmitters in stimulated neurones. They have been shown to be effective in states of enhanced neuronal activation during inflammation and nerve lesioning (spinal cord injury, diabetic neuropathy, neuropathic cancer pain, HIV associated neuropathy) [132, 133], which may be associated with the increased expression of the $\alpha 2 \delta$ subunit [133]. Pregabalin has been assessed in hip and knee OA in a 12-week, double blind, placebocontrolled, multi-center study in 296 patients. No response 
was observed in patients with knee OA but patients with hip OA experienced improvement in sleep quality and improvements in the Western Ontario and McMaster University Osteoarthritis Index (WOMAC) pain subscale [134].

\section{Neurotrophins and their receptors}

Neurotrophins and their receptors represent an important family of regulatory proteins essential for sensory nerve development, survival and the determination of neurochemical phenotype important for the regulation of excitability $[135,136]$. Several neurotrophins (NTs) have been identified, including NGF, brain derived growth factor (BDNF) and NT3 and NT4/5. Each NT binds with high affinity to a receptor tyrosine kinase (Trk): NGF to TrkA, BDNF and NT4/5 to TrkB and NT3 to TrkC. NT3 also binds with TrkA and TrkB. Mature NTs also bind to a structurally distinct receptor, p75, which affects neuronal development through downstream signaling. NTs arise from pro-NT precursors following extracellular cleavage by metalloproteinases and plasmin. It is notable that pro-NTs may signal through the p75 receptor in a manner that opposes the effects of NTs, for example, to produce apoptosis rather than cell survival [137].

NGF has been most studied with respect to inflammatory hyperalgesia as its production is unregulated by inflammation in macrophages, fibroblasts and Schwann cells. NGF has emerged as a key regulator of sensory neurone excitability and as an important mediator of injury-induced nociceptive and neuropathic pain [138-140]. Thus, NGF acts via TrkA and p75 to activate a number of other kinase pathways, for example, that of p38 kinase, leading to altered gene transcription and increased synthesis of sensory neuropeptides (substance $P$, CGRP), ion channels (TRPV1, NaV1.8, ASIC3) [141-143], membrane receptors such as bradykinin and P2X3 [144,145], and structural molecules, including neurofilament and channel anchoring proteins such as the annexin light chain p11 [121].

Increased expression and release of NGF have been demonstrated in several painful conditions in animal models (for example, UV injury, surgical injury) [146,147] and in human conditions, including arthritis, cystitis, prostitis and headache [148-150]. Administration of exogenous NGF induces thermal and mechanical hyperalgesia in animals and humans [151,152], which is considered to be due, in part, to mast cell degranulation and by directly increasing sensory neuronal excitability [153].

Only a few small molecule NGF antagonists are available, but ALE0540, which inhibits the binding of NGF to TrkA and p75, and PD90780, which inhibits NGF binding to p75, have been proposed to have efficacy in chronic pain models $[154,155]$. The importance of NGF has also received clinical confirmation since RN624, a humanized ant-NGF monoclonal antibody, has been reported to be efficacious in reducing pain and improved mobility in OA [156]. Anti-NGF monoclonal antibody therapy appears to be an attractive thera- peutic approach with the potential for long lasting pain treatment, similar in efficacy to morphine, without compromising physiological nociception.

NGF also induces the synthesis and accumulation of BDNF in peptide-containing sensory neurones following painful nerve injury [135]. Release of BDNF in the spinal dorsal horn increases spinal excitability and pain sensitization via TrkB receptors. This initiates a variety of effects, including direct neural excitation, activation of a signaling cascade via the phophorylation of NMDA receptors, and altered regulation of the neural chloride-ion transporter that contributes to pain hypersensitivity [157]. In addition, spinal BDNF administration induces thermal and mechanical allodynia whereas antiBNDF neutralization or TrkB IgG administration reduces inflammation or nerve injury hypersensitivity in a number of animal models $[139,158,159]$.

Finally, GDNF represents an extensive family of ligands and membrane receptor complexes that have an important role in regulating peripheral and central neural phenotypes. GDNF related ligands include neurturin and artemin, which act via the complex c-Ret proto-oncogene receptor tyrosine kinase and co-receptors glial cell line-derived neurotrophic factor receptor (GFR) $\alpha 1, \alpha 2, \alpha 3$ and $\alpha 4$. Although there appears not to be a specific role in inflammation, GDNF has been shown to have neuroprotective and restorative properties in a number of neurodegenerative and neuropathic pain states [135]. Specifically, GDNF treatment has been shown to restore peripheral sensory neurone function, including peptide and ion channel expression patterns, following painful peripheral nerve injury accompanied by an attenuation of pain behaviors. Unfortunately, clinical observations using GDNF have shown unacceptable side effects, such as weight loss and allodynia, which has discouraged therapeutic developments [160].

\section{Botulinum toxin}

Another approach to pain modulation has been the use of botulinum toxins (BoTNs). The mechanism of action of BoTN is related to inhibition of transmitter release from motor fibers through proteolytic cleavage of a number of synaptosomal regulatory proteins (soluble $\mathrm{N}$-ethyl maleimide-sensitive fusion protein attachment protein receptors (SNAREs), syntaxin, synaptosome-associated protein of $25 \mathrm{kDa}$ (SNAP-25) and synaptobrevin). More recent studies have also indicated potential for inhibition of neuropeptide transmitter release from small afferent nerves [161,162]. In keeping with this, BoNT has been shown to provide long lasting pain relief following administration into human OA joints [163] and improve bladder dysfunction in overactive bladder patients. This was correlated with loss of both P2X3 and VR1 receptors in the urinary bladder [164].

\section{Functional assessment and animal models}

Predicting efficacy of novel targets in patients using preclinical models has been a key theme in analgesic drug 
development. Animal models of cutaneous inflammatory pain were developed initially as pharmacodynamic assays of antiinflammatory drug activity, particularly for NSAIDs. Typically, primary endpoints were reduction in hindpaw swelling, induced by Freund's adjuvant or carrageenan, and reflex limb withdrawal to a mechanical stimulation. At this time, the lack of activity of NSAIDs in models of acute nociceptive pain, such as the tail-flick [165] and hot plate assays [166], raised an awareness that clinical pain pathophysiology and pharmacology, in which a sensitized state is induced in the presence of inflammation (or nerve damage), differ significantly from normal physiological pain observed in healthy animals. From that time a major emphasis on models that reproduce specific elements of chronic pain have allowed the systematic mechanistic exploration of excitability changes in pain pathways [167]. This has also provided the building blocks for rational translation of findings in animal models, for example, pharmacodynamic/pharmacokinetic measures of the reduction of neuro-excitability and pain behavior to reduction of clinical pain.

However, there is concern that current models still lack the tissue and disease specificity of some key patient populations. OA pain is an example where an improved clinical understanding of joint pathology and its relationship to pain can focus disease specific approaches. Magnetic resonance imaging studies have reported significant association of specific tissue pathologies such as subchondral bone lesions, synovial thickening and knee effusion with pain [168-170]. These clinical observations, along with histopathology samples from joint arthroplasty, synovial fluid collections and so on, allow an investigation of specific elements of structural pathology, the potential mediators involved and the presence/absence of pain. It is clear that while no single animal model replicates human OA, specific elements can be modeled in animals. The choice of model, interpretation of endpoints and translation to the clinic are critical future challenges in therapeutic development.

While a comprehensive analysis of OA models is beyond the scope of this review, recent developments have focused on intra-articular injection of monoiodoacetate into rodent femorotibial joint or surgical destabilization of the joint in rats and guinea pigs. These models seek to emulate aspects of OA pathology. For example in the monoiodoacetate model following chondrocytic cell death and cartilage fragmentation, a subchondral bone lesion develops with active resorption and remodeling of cancellous bone typically by day 21 . Inflammation is observed as mononuclear cell infiltrates and hyperplastic synovium but this is transient and resolves [171-173]. In addition, mechanical allodynia (weight bearing) $[173,174]$ and mechanical hyperalgesia (von Frey hair stimulation) [175] are exhibited. Further characterization shows that, in the early stages, there is sensitivity to NSAIDs $[173,174]$ whereas later stages appear to demonstrate evidence of nerve damage with elevated activating

\author{
This review is part of a series on \\ Arthritis and pain \\ edited by Jason McDougall. \\ Other articles in this series can be found at \\ http://arthritis-research.com/articles/ \\ review-series.asp?series=ar_pain
}

transcription factor-3 (ATF-3) immunoreactivity in innervating cell bodies of lumber-DRG and sensitivity to morphine, amitriptyline and gabapentin $[173,176]$. The correlation of bone lesion with onset of ATF-3 immunoreactivity makes osteoclast-induced injury or mechanical compression of bone $\mathrm{A} \delta$ and $\mathrm{C}$-fibres candidate mechanisms for nerve damage. These observations indicate the importance of relating animal model histopathology with clinical samples to gain understanding of putative analgesic targets and to propose clearer hypotheses for testing. Detailed translation of this kind may also be applied to the analysis of OA heterogeneity and the evaluation of personalized approaches to OA treatments.

\section{Summary and conclusions}

Clinical presentation of $\mathrm{OA}$ is dominated by pain during joint use and often at rest. Effective pain therapy has been a key therapeutic challenge not only in OA but in a variety of chronic pain disorders. OA represents a complexity of pain conditions, including manifestations of both nociceptive and neuropathic mechanisms driven by joint pathophysiology and abnormal excitability in peripheral and central pain pathways. A mechanisms-based focus on the key molecular drivers of neural excitability offers a multiplicity of possible intervention points. Indeed, a rich diversity of molecular events has been identified in the pathophysiology of chronic pain, representing most families of regulatory proteins. Many molecules are inflammatory mediators and their key receptors (kinins, mPGES) while others, such as ion channels (TRPV1, NaV1.7) and NTs (NGF), are key regulators of membrane excitability and cellular phenotype. We have highlighted these and a number of other important targets for future pain therapy, noting in particular evidence that relates to their participation in animal model systems of OA, translatability to humans as well as efficacy in the clinical setting. The future treatment of pain appears optimistic but will require the systematic evaluation of emerging opportunities.

\section{Competing interests}

Both authors are employees and shareholders of AstraZeneca Pharmaceuticals.

\section{References}

1. Bellamy N, Sothern RB, Campbell J: Rhythmic variations in pain perception in osteoarthritis of the knee. J Rheumatol 1990, 17: 364-372.

2. Bellamy N, Sothern RB, Campbell J, Buchanan WW: Rhythmic variations in pain, stiffness and manual dexterity in hand osteoarthritis. Ann Rheum Dis 2002, 61:1075-1080. 
3. Creamer P, Hunt M, Dieppe P: Pain mechanisms in osteoarthritis of the knee: Effect of intra-articular anaesthetic. J Rheumatol 1996, 23:1031-1036.

4. Crawford RW, Gie GA, Ling RS, Murray DW: Diagnostic value of intra-articular anaesthetic in primary osteoarthritis of the hip. J Bone Joint Surg 1998, 80:279-281.

5. Kosek E, Ordeberg G: Lack of pressure pain modulation by heterotopic noxious conditioning stimulation in patients with painful osteoarthritis before, but not following, surgical pain relief. Pain 2000, 88:69-78.

6. Buffington ALH, Hanlon CA, McKeown MJ: Acute and persistent pain modulation of attention-related anterior cingulated fMRI activations. Pain 2005, 113:172-184.

7. Rowbotham MC, Kidd BL, Porreca F: Role of central sensitization in chronic pain: Osteoarthritis and rheumatoid arthritis compared to neuropathic pain. In Proceedings of the 11th World Congress on Pain. August 21 - 26th 2005, Sydney, Australia. Edited by Flor H, Kalso E, Dostrovsky J. Seattle; IASP Press: 2006.

8. Fraenkel M, Bogardus ST, Concato J, Wittink DR: Treatment options in knee OA. Arch Intern Med 2004, 164:1299-1304.

9. Yaksh TL: Pharmacology and mechanisms of opioid analgesic activity. Acta Anaesthes Scand 1997, 41:94-111.

10. Hurley RW, Hammond DL: The analgesic effects of supraspinal $\mu$ and $\delta$ opioid receptor agonists are potentiated during persistent inflammation. J Neurosci 2000, 20:1249-1259.

11. Sawynok J: Topical and peripherally acting analgesics. Pharmacol Rev 2003, 55:1-20.

12. Likar R. Schafer M. Paulak F. Sittl R. Pipam W. Schalk H. Geissler D. Bernatzky G: Intraarticular morphine analgesia in chronic pain patients with osteoarthritis. Anesth Analg 1997, 84:13131317.

13. Menendez L, Lastra A, Meana A, Hidalgo A, Baamonde A: Analgesic effects of loperamide in bone cancer pain in mice. Pharmacol Biochem Behav 2005, 81:114-121.

14. Whiteside GT, Boulet JM, Walker K: The role of central and peripheral mu opioid receptors in inflammatory pain and edema: a study using morphine and DiPOA ([8-(3,3-diphenylpropyl)-4-oxo-1-phenyl-1,3,8-triaza-spiro[4.5]dec-3-yl]-acetic acid). J Pharmacol Exp Ther 2005, 314:1234-1240.

15. Dray A: Alternatives to mu-opioid analgesics: delta-opioid and galanin-receptor selective compounds. In Progress in Pain Research and Management. Edited by Kalso E, McQuay HJ, Wiesenfeld-Hallin Z. Seattle: IASP Press; 1999:269-280.

16. Cahill CM, Morinville A, Lee M-C, Vincent J-P, Collier B, Beaudet $A$ : Prolongedmorphine treatment targets $\delta$ opioid receptors to neuronal plasma membranes and enhances $\delta$-mediated antinociception. J Neurosci 2001, 21:7598-7607.

17. Koblish M, LaBuda CJ, Ajello CW, Gu M, Zhou OJ, Tuthill PA, Chu G, Le Bourdonnec B, Dolle RE, Little PJ: Anti- hyperalgesic activity of a novel delta-opioid receptor agonist. Soc Neurosci Abst 2005, 490.14.

18. Dray A: Kinins and their receptors in hyperalgesia. Can J Pharmacol 1997, 75:704-712.

19. Dray A, Perkins MN: Bradykinin and inflammatory pain. Trends Neurosci 1993, 16:99-104.

20. Wotherspoon G, Winter J: Bradykinin B1 receptor is constitutively expressed in the rat sensory nervous system. Neurosci Letts 2000, 294:175-178.

21. Shughrue PJ, Ky B, Austin CP: Localization of B1 bradykinin receptors mRNA in the primate brain and spinal cord: an in situ hybridization study. J Comp Neuro/ 2003, 46:372-384.

22. Levy D, Zochodne DW: Increased mRNA expression of the B1 and B2 bradykinin receptors and antinociceptive effects of their antagonists in an animal model of neuropathic pain. Pain 2000, 86:265-271.

23. Fox A, Wotherspoon G, McNair K, Hudson L, Patel S, Gentry C, Winter L: Regulation and function of spinal and peripheral neuronal $B(1)$ bradykinin receptors in inflammatory mechanical hyperalgesia. Pain 2003, 104:683-691.

24. Ferreira, J, Beirith A, Mori MAS, Araujo RC, Bader M, Pesqero JB, Calixto JB: Reduced nerve injury induced neuropathic pain in kinin B1 receptor knock-out mice. J Neurosci 2005, 25:24052412.

25. Eisenbarth $H$, Rukwied R, Petersen M, Schmelz M: Sensitization to bradykinin B1 and B2 receptor activation in UV-B irradiated human skin. Pain 2004, 110:197-204.
26. Vellani $\mathrm{V}$, Zachrisson O, McNaughton PA: Functional bradykinin $B 1$ receptors are expressed in nociceptive neurons and are upregulated by the neurotrophin GDNF. J Physio/ 2004, 560: 391-401.

27. Marceau F, Hess JF, Bachvarov DR: The B1 receptors for kinins. Pharmacol Rev 1998, 50:357-386.

28. Liang YF, Haake B, Reeh PW: Sustained sensitization and recruitment of rat cutaneous nociceptors by bradykinin and a novel theory of its excitatory action. J Physio/ 2001, 532:229239.

29. Fox A, Kaur S, Li B, Panasar M, Saha U, Davis C, Dragoni I, Colley S, Ritchie T, Bevan S, et al.: Antihyperalgesic activity of a novel nonpeptide bradykinin $B 1$ receptor antagonist in transgenic mice expressing the human B1 receptor. Br J Pharmacol 2005, 144:889-899.

30. Stewart JM: Bradykinin antagonists: discovery and development. Peptides 2004, 25:527-732.

31. Burgess GM, Perkins MN, Rang HP, Campbell EA, Browen MC, McIntyre P, Urban L, Dziadulewicz EK, Ritchie TJ, Hallet A, et al.: Bradyzide, a potent nonpeptide B2 bradykinin receptors antagonist with long lasting oral activity in animal models of inflammatory hyperalgesia. Br J Pharmaco/ 2000, 129:77-86.

32. Gougat J, Ferrari B, Lionel S, Planchenault C, Poncelet $M$, Maruani J, Alonso R, Cudennec A, Croci T, Guagnini F, et al.: SSR240612 [(2R)-2-[((3R0-3-(1,3-benzodiol-5-yl)-3-\{[(6-methoxy2-napthyl)sulfonyl]amino\}propanoyl)amino]-3-(4-\{[2R,6S)-2,6dimethylpiperidyl]methyl\}phenyl\}-N-isoproyl-Nmethylpropana mide hydrochloride], a new nonpeptide antagonist of the bradykinin B1 receptor: biochemical and pharmacological characterization. J Pharmacol Exp Ther 2005, 309:661-669.

33. Gabra $\mathrm{BH}$, Sirois P: Beneficial effects of chronic treatment with the selective bradykinin B1 receptor antagonists, R-715 and R-953, in attenuating streptozotocin-diabetic thermal hyperalgesia. Peptides 2003, 24:1131-1139.

34. Flechtenmacher J, Talke M, Veith D, Heil K, Gebauer A, Schoenharting $M$ : Icatibant induces pain relief in patients with osteoarthritis of the knee. Proceedings of the 9th World Congress of the OsteoArthritis Research Society Internation (OARSI). December 2-5 2004, Chicago. 12:P332.

35. Fox A, Bevan S: Therapeutic potential of cannabinoid receptor agonists as analgesic agents. Expert Opin Investig Drugs 2005, 14:695-703.

36. Rice ASC, Farquhar-Smith WP, Nagy I: Endocannabinoids and pain: spinal and peripheral analgesia in inflammation and neuropathy. Prostaglandins Leukot Essent Fatty Acids 2002, 66: 243-256.

37. Mbvundula EC, Bunning RA, Rainsford KD: Arthritis and cannabinoids: HU-210 and Win-55,212-2 prevent IL-1alphainduced matrix degradation in bovine articular chondrocytes in vitro.J Pharm Pharmaco/ 2006, 58:351-358.

38. Kreitzer Ac, Regeher WG: Retrograde signaling by endocannabinoids. Curr Opin Neurobio/ 2002, 12:324-330.

39. de Novellis V, Mariani L, Palazzo E, Vita D, Marabese I, Scafuro M, Rossi F, Maione S: Periaqueductal grey CB1 cannabinoid and metabotropic glutamate subtype 5 receptors modulate changes in rostral ventromedial medulla neuronal activities induced by subcutaneous formalin in the rat. Neuroscience 2005, 134:269-281.

40. Walker JM, Huang SM, Strangman NM, Tsou K, Sanudo-Pena MC: Pain modulation by release of the endogenous cannabinoid anandamide. Proc Natl Acad Sci USA 1999, 96:1219812203.

41. Campbell FA, Tramer MR, Carroll D, Reynolds DJ, Moore RA, McQuay $\mathrm{HJ}$ : Are cannabinoids an effective and safe treatment option in the management of pain? A quantitative systematic review. $B M J$ J 2001, 323:13-16.

42. Dyson A, Peacock M, Chen A, Courade J-P, Yaqoob, Groark A, Brain C, Loong Y, Fox A: Antihyperalgesic properties of the cannabinoid CT-3 in chronic neuropathic and inflammatory pain states in the rat. Pain 2005, 116:129-137.

43. Richardson JD, Kilo S, Hargreaves KM: Cannabinoids reduce hyperalgesia and inflammation via interactions with peripheral CB1 receptors. Pain 1998, 75:111-119.

44. Karst M, Salim K, Burstein S, Conrad I, Hoy L, Schneider U: Analgesic effect of the synthetic cannabinoid CT-3 on chronic neuropathic pain: a randomized controlled trial. JAMA 2003, 290: 1757-1762. 
45. Malan TP, Ibrahim MM, Lai J, Vanderah TW, Makriyannis A. Porreca F: CB2 cannabinoid receptor agonists: pain relief without psychoactive effects? Curr Opin Pharmacol 2003, 3: 62-67.

46. Labuda CJ, Koblish M, Little PJ: Cannabinoid CB2 receptor agonist activity in the hindpaw incision model of postoperative pain. Eur J Pharmacol 2005, 527:172-175.

47. Valenzano KJ, Tafesse L, Lee G, Harrison JE, Bulet JM, Gottshall SL, Mark L, Pearson MS, Miller W, Shan S, et al.: Pharmacological and pharmacokinetic characterization of the cannabinoid receptor 2 agonist GW405833, utilizing rodent models of acute and chronic pain, anxiety, ataxia and catalepsy. $\mathrm{Neu}$ ropharmacology 2005, 48:658-672.

48. Elmes SJR, Winyard LA, Medhurst A, Clayton SJ, Wilson NM, Kendall AW, Chapman V: Activation of CB1 and CB2 receptors attenuates the induction and maintenance of inflammatory pain in the rat. Pain 2005, 118:327-335.

49. Sokal DM, Elmes SJR, Kendall DA, Chapman V: Intraplantar injection of anandamide inhibits mechanically-evoked responses of spinal neurons via activation of $\mathrm{Cb} 2$ receptors in anaesthetized rats. Neuropharmacology 2003, 45:404-411.

50. Cravatt BF, Lichtman AH: The endogenous cannabinoid system and its role in nociceptive behavior. J Neurobio/ 2004, 61:149-160.

51. Cravatt BF, Demarest K, Patricelli MP, Bracey MH, Giang DK, Martin BR, Lichtman AH: Supersensitivity to anandamide and enhanced endogenous cannabinoid signaling in mice lacking fatty acid amide hydrolyse. Proc Natl Acad Sci USA 2001, 98: 9371-9376.

52. Lichtman AH, Leung D, Shelton CC, Saghatelian A, Hardouin C, Boger DL, Cravatt BJ: Reversible inhibitors of fatty acid amide hydrolase that promote analgesia: evidence for an unprecedented combination of potency and selectivity. J Pharmacol Exp Ther 2004, 311:441-448.

53. Chang L, Luo L, Palmer JA, Sutton S, Wilson SJ, Barbier AJ, Breitenbucher JG, Chaplan SR, Webb M: Inhibition of fatty acid amide hydrolase produces analgesia by multiple mechanisms. Br J Pharmacol 2006, 148:102-113.

54. Cichewicz DL, McCarthy EA: Antinociceptive synergy between D9 tetrahydrocannabinol and opioids after oral administration. J Pharmacol Exp Ther 2003, 304:1010- 1015.

55. England S, Bevan S, Dougherty RJ: PGE2 modulate the tetrodotoxin-resistant sodium current in neonatal dorsal root ganglion neurons via the cyclic AMP-protein kinase A cascade. J Physiol 1996, 495:429-440.

56. Gold MS, Levine JD, Correa M: Modulation of TTX-R I Na by PKC and PKA and their role in PGE2-induced sensitization of rat sensory neurons in vitro. J Neurosci 1998, 18:1034510355.

57. Bar K-J, Natura G, Telleria-Diaz A, Tascher $P$, Vogel R, Vasques $E$, Schaible H-G, Ebersberger A: Changes in the effect of spinal prostaglandin E2 during inflammation: prostaglandin E9EP1EP4) receptors in spinal nociceptive processing of input from the normal and inflamed knee joint. J Neurosci 2004, 24:642651.

58. Yaksh TL, Dirig DM, Conway CM, Svensson C, Luo ZD, Isakson PC: The acute hyperalgesic action of non-steroidal, anti-inflammatory drugs and release of spinal prostaglandin E2 is mediated by the inhibition of constitutive spinal cyclooxygenase-2 (COX-2) but not COX-1. J Neurosci 2001, 21:5847-5853

59. Harvey RJ, Depner UB, Wassle H, Ahmadi S, Heidl C, Reinold H, Smart TG, Harvey K, Schultz B, Abo-Salem OM, et al:: Gly $\alpha 3$ : an essential target for spinal PGE2-mediated inflammatory pain sensitization. Science 2004; 304:884-887.

60. Chandrasekharan NV, Dai H, Roos KLT, Evanson NK, Tomsik J, Elton TS, Simmons DL: COX-3, a cyclooxygenase-1 variant inhibited by acetaminophen and other analgesic/antipyretic drugs: Cloning, structure, and expression. Proc Natl Acad Sci USA 2002, 99:13926-13931.

61. Mitchell JA, Warner TD: COX isoforms in the cardiovascular system: understanding the activities of non-steroidal antiinflammatory drugs. Nat Rev Drug Discov 2006, 5:75-85.

62. Jakobsson PJ, Thoen S, Morgenstern R, Samuelsson B: Identification of human prostaglandin $E$ synthase: a microsomal , glutathione-dependent, inducible enzyme, constituting a potential novel drug target. Proc Natl Acad Sci USA 1999, 96: 7220-7225.
63. Claveau D, Sirinyan M, Guay J, Gordon R, Chan C-C, Bureau Y, Riendeau $D$, Mancini JA: Microsomal prostaglandin synnthase1 is a major terminal synthase that is selectively upregulated during cyclooxygenase-2-dependent prostaglandin E2 production in the rat adjuvant-arthritis model. J Immunol 2003 170:4738-4744.

64. Trebino CE, Stock JL, Gibbons CP, Naiman BM, Wachtmann TS, Umland JP, Pandher K, Lapointe JM, Saha S, Roach ML, et al.: Impaired inflammatory and pain responses in mice lacking an inducible prostaglandin E synthase. Proc Natl Acad Sci USA 2003, 100:9044-9049.

65. Sommer C, Kress M: Recent findings on how proinflammatory cytokines cause pain: peripheral mechanisms in inflammatory and neuropathic hyperalgesia. Neurosci Lett 2004, 361:184187.

66. Ohtori S, Takahashi K, Moriya H, Myers RR: TNF-alpha and TNFalpha receptor type 1 upregulation in glia and neurons after peripheral nerve injury: studies in murine DRG and spinal cord. Spine 2004, 29:1082-1088.

67. Pollock J, McFarlane SM, Connell MC, Zehavi U, Vandenabeele P, MacEwan DJ, Scott RH: TNF-alpha receptors simultaneously activate $\mathrm{Ca} 2+$ mobilisation and stress kinases in cultured sensory neurons. Neuropharmacology 2002, 42:93-106.

68. Schafers M, Marziniak M, Sorkin LS, Yaksh TL, Sommer C: Cyclooxygenase inhibition in nerve-injury- and TNF-induced hyperalgesia in the rat. Exp Neuro/ 2004, 185:160-168.

69. Schafers M, Sorkin LS, Geis C. Shubayev VI: Spinal ligation induces transient upregulation of tumor necrosis factor receptors 1 and 2 in injured and adjacent uninjured dorsal root ganglia of rat. Neurosci Lett 2003, 347:179-182.

70. Grunke M, Schulze-Koops H: Successful treatment of inflammatory knee osteoarthritis with tumour necrosis factor blockade. Ann Rheum Dis 2006, 65:555-556.

71. Watkins LR, Maier S: Beyond neurons: evidence that immune and glial cells contribute to pathological pain states. Physiol Rev 2002, 82:981-1011.

72. Zhang N, Inan S, Cowan A, Sun R, Wang JM, Rogers TJ, Caterina $M$, Oppenheim JJ: A proinflammatory chemokine, CCL3, sensitizes the heat- and capsaicin-gated ion channel TRPV1. Proc Natl Acad Sci USA 2005, 102:4536-4541.

73. Oh SB, Tran PB, Gillard SE, Hurley RW, Hammond DL, Miller RJ: Chemokines and glycoprotein 120 produce pain hypersensitivity by directly exciting primary nociceptive neurons. $J \mathrm{Neu}-$ rosci 2001, 21:5027-5035

74. Weidler C, Holzer C, Harbuz M, Hofbauer R, Angele P, Scholmerich J, Straub RH: Low density of sympathetic nerve fibres and increased density of brain derived neurotrophic factor positive cells in RA synovium. Ann Rheum Dis 2005, 64:13-20.

75. Miller LE, Wiedler C, Falk W, Angele P, Schaumberger J, Scholmerich J, Straub R: Increased prevalence of semaphorin $3 C$, a repellent of sympathetic nerve fibres in synovial tissue of patients with rheumatoid arthritis. Arthritis Rheum 2004, 50:1156-1163.

76. Niissalo S, Hukkanen M, Imai S, Tornwall J, Konttinen YT: Neuropeptides in experimental and degenerative arthritis. Ann New York Acad Sci 2002, 966:384-399.

77. Zhang JM, LI H, Munir MA: Decreasing sympathetic sprouting in pathological sympathetic ganglia: a new mechanism for treating neuropathic pain using lidocaine. Pain 2004, 109:143149.

78. Shinder V, Govrin-Lippmann R, Cohen S, Belenky M, Ilin P, Fried K, Wilkinson HA, Devor M: Structural basis of sympatheticsensory coupling in rat and human dorsal root ganglia following peripheral nerve injury. J Neurocytol 1999, 28:743-761.

79. Sato J, Perl ER: Adrenergic excitation of cutaneous pain receptors induced by peripheral nerve injury. Science 1991, 251: 1608-1610.

80. Lee DH, Liu X, Kim HT, Chung K, Chung JM: Receptor subtype mediating the adrenergic sensitivity of pain behavior and ectopic discharges in neuropathic Lewis rats. J Neurophysiol 1999, 81:2226-2233.

81. Ali Z, Raja SN, Wesselmann U, Fuchs PN, Meyer, RA, Campbell $\mathrm{JN}$ : Intradermal injection of norepinephrine evokes pain in patients with sympathetically maintained pain. Pain 2000,88 : 161-168.

82. McNearney T, Baethge BA, Cao S, Alam R, Lisse JR, Westlund $\mathrm{KN}$ : Excitatory amino acids, TNF $\alpha$ and chemokine levels in 
synovial fluids of patients with active arthropathies. Clin Exp Immunol 2004, 137:621-627.

83. Neugebauer V: Glutamate receptor ligands. Hand Exp Pharmacol 2007, 177:217-249.

84. Szekely Jl, Torok K, Mate G: The role of ionotropic glutamate receptors in nociception with special regard to the AMPA binding sites. Curr Pharmaceut Des 2002, 8:887-912.

85. Merle B, Itzstein C, Delmas PD, Chenu C: NMDA glutamate receptors are expressed by osteoclast precursors and involved in the regulation of osteoclastogenesis. J Cell Biochem 2003, 90:424-436.

86. Salter DM, Wright MO, Millward-Sadler SJ: NMDA receptor expression and roles in human articular chondrocyte mechanotransduction. Biorheology 2004, 41:273-281.

87. Danysz W, Parsons CG: GlycineB recognition site of NMDA receptors and its antagonists. Amino Acids 1998, 14:205-206.

88. Quartaroli M, Fasdelli N, Bettelini L, Maraia G, Corsi M: GV196771A, an NMDA receptor/glycine site antagonist, attenuates mechanical allodynia in neuropathic rats and reduces tolerance induced by morphine in mice. Eur J Pharmacol 2001, 430:219-227.

89. Wallace MS, Rowbotham MC, Katz NP, Dworkin RH, Dotson RM, Galer BS, Rauck RL, Backonja MM, Quessy SN, Meisner PD: A randomized, double blind, placebo-controlled trial of a glycine antagonist in neuropathic pain. Neurology 2002, 59:1694-1700.

90. Taniguchi K, Shinjo K, Mizutani M, Shimada K, Ishikawa T, Menniti F, Nagahisa A: Antinociceptive actions of CP-101,606, an NMDA receptor NR2B subunit antagonist. $\mathrm{Br} J$ Pharmacol 1997, 12:809-812.

91. Hudson LJ, Bevan S, McNair K, Gentry C, Fox A, Kuhn R, Winter $\mathrm{J}$ : Metabotropic glutamate receptor 5 up-regulation in A-fibers after spinal nerve injury: 2-Methyl-6-(phenylethynyl)-pyridine (MPEP) reverses the induced thermal hyperalgesia. $J \mathrm{Neu}$ rosci 2002, 22: 2660-2668.

92. Dogrul A, Ossipov MH, Lai J, Malan TP, Porecca F: Peripheral and spinal antihyperalgesic activity of SIB-1757, a metabotropic glutamate receptor (mGluR5) antagonist, in experimental neuropathic pain in rats. Neurosci Letts 2000, 292: 115-118.

93. Zhu CZ, Wilson SG, Mikusa JP, Wismer CT, Gauvin DM, Lynch JJ 3rd, Wade CL, Decker MW, Honore P: Assessing the role of metabotropic glutamate receptor 5 in multiple nociceptive modalities. Eur J Pharmacol 2004, 506:107-118.

94. Boxall SJ, Berthele A, Laurie DJ, Sommer B, Zieglgansberger W, Urban L, Tolle TR: Enhanced expression of metabotropic glutamate receptor 3 messenger RNA in the rat spinal cord during ultraviolet irradiation induced peripheral inflammation. Neuroscience 1998, 82:591-602.

95. Chiechio S, Caricasole A, Barletta E, Storto M, Catania MV, Copani A, Vertechy M, Nicolai R, Calvani M, Melchiorri D, Nicoletti $\mathrm{F}$ : L-Acetylcarnitine induces analgesia by selectively upregulating mGlu2 metabotropic glutamate receptors. Mol Pharm 2002, 61:989-996.

96. Vellani V, Mappleback S, Moriondo A, Davis JB, McNaughton PA: Protein kinase $C$ activation gating of the vanilloid receptor VR1 by capsaicin, protons, heat and anandamide. J Physiol 2001, 534:813-825.

97. Szallasi A, Blumberg PM: Vanilloid (Capsaicin) receptors and mechanisms. Pharmacol Rev 1999, 51:159-212.

98. Cantillon M, Vause E, Sykes D, Moon A, Hughes S: Safety, tolerability and efficacy of ALGRX 4975 in osteoarthritis (OA) of the knee. Journal of Pain 2005, 6(3): S39.

99. Garcia-Martiez C, Humet M, Planells-Casas R, Gomis A, Capri M, Viaa F, de la Pena, E, Sachez-Baez F, Carbonell T, de Felipe C, et al:: Attenuation of thermal nociception and hyperalgesia by VR1 blockers. Proc Natl Acad Sci USA 2002, 99:2374-2379.

100. Gavva NR, Tamir R, Qu Y, Klionsky L, Zhang TJ, Immke D, Wang J, Zhu D, Vanderah TW, Porreca F, Doherty EM, et al:: AMG 9810 [(E)-3-(4-t-butylphenyl)- $\mathrm{N}$-(2,3-dihydrobenzo[b][1,4] dioxin-6yl)acrylamide], a novel vanilloid receptor 1 (TRPV1) antagonist with antihyperalgesic properties. J Pharmacol Exp Ther 2005, 313:473-484.

101. Chizh B, Napolitano A, O'Donnell M, Wang J, Brooke A, Lai R, Aylott M, Bullman J, Gray E, Williams P, Appleby J: The TRPV1 antagonist SB705498 attenuates TRPV1 receptor mediated activity and inhibits inflammatory hyperalgesia in humans: Results from a Phase 1 study. Journal of Pain 2006, 7 (4): S42.
102. Bandell M, Story GM, Hwang SW, Viswanath V, Eid SR, Petrus MJ, Earley TJ, Pataapouian A: Noxious cold ion channel TRPA1 is activated by pungent compounds and bradykinin. Neuron 2004, 41:849-853.

103. Band-Ward PA, Humphrey PP: P2x receptor mediated ATPinduced primary nociceptive neurone activation. J Autonom Nerv Syst 2000, 81:146-151.

104. Honore P, Kage K, Mikusa J, Watt AT, Johnston JF, Wyatt JR, Faltynek CR, Jarvis MF, Lynch K: Analgesic profile of intrathecal P2X(3) antisense oligonucleotide treatment in chronic inflammatory and neuropathic pain states in rats. Pain 2002, 99:1119.

105. Jarvis MF, Burgard EC, McGaraughty S, Honore $P$, Lynch K, Brennan TJ, Subieta A, van Biesen T, Cartmell J, Bianchi B, et al.: A-317491, a novel potent and selective non nucleotide antagonist of $\mathrm{P} 2 \mathrm{X}(3)$ and $\mathrm{P} 2 \mathrm{X}(2 / 3)$ receptors, reduces chronic inflammatory and neuropathic pain in the rat. Proc Natl Acad Sci USA 2002, 99:17179-17184.

106. Tsuda M, Shigemoto-Mogami Y, Koizumi S, Mizokoshi A, Kohsaka $\mathrm{S}$, Salter MW, Inoue K: P2X4 receptors induced in spinal microglia gate tactile allodynia after nerve injury. Nature 2003, 424:778-783.

107. Deuchars SA, Atkinson L, Brooke RE, Musa H, Milligan CJ, Batten TFC, Buckley NJ, Parson SH, Deuchars J: Neuronal P2X7 receptors are targeted to presynaptic terminals in the central and peripheral nervous systems. J Neurosci 2001, 21:7143-7152.

108. Chessell IP, Hatcher JP, Bountra C, Michel AD, Hughes JP, Green $\mathrm{P}$, Egerton J, Murfin M, Richardson J, Peck WL, et al.: Disruption of the P2X7 purinoceptor gene abolishes chronic inflammatory and neuropathic pain. Pain 2005, 114: 386-396.

109. Chaplan SR, Guo H-Q, Lee DH, Luo L, Liu C, Kuei C, Velumian AAL, Butler MP, Brown SM, Dubin AE: Neuronal hyperpolarization-activated pacemaker channels drive neuropathic pain. $J$ Neurosci 2003, 23:1169-1178.

110. Yao H, Donnelly DF, Ma C, LaMotte RH: Upregulation of the hyperpolarization activation cation current after chronic compression of the dorsal root ganglion. J Neurosci 2003, 23: 2069-2074.

111. Giatromanolaki A, Sivridis E, Maltezos E, Athanassou N, Papazoglou D, Gatter KC, Harris AL, Koukourakis MI: Upregulated hypoxia inducible factor-1alpha and -2alpha pathway in rheumatoid arthritis and osteoarthritis. Arthritis Res Ther 2003 5:R193-201.

112. Leffler A, Monter B, Koltzenburg M: The role of the capsaicin receptor TRPV1 and acid sensing ion channels (ASICs) in proton sensitivity of subpopulation of primary nociceptive neurons in rats and mice. Neuroscience 2006, 139:699-709.

113. Dube GR, Lehto SG, Breese NM, Baker SJ, Wang X, Matulenko MA, Honore P, Stewart AO, Moreland RB, Brioni JD: Electrophysiological and in vivo characterization of A-317567, a novel blocker of acid sensing ion channels. Pain 2005, 117:88-96.

114. Matzner O, Devor M: Hyperexcitability at sites of nerve injury depends on voltage sensitive sodium channels. J Neurophysiol 1994, 72:349-359.

115. Eglen RM, Hunter JC, Dray A: lons in the fire: recent ionchannel research and approaches to pain therapy. Trends Pharmacol Sci 1999, 8:337-342.

116. Devor M: Sodium channels and mechanisms of neuropathic pain. Pain 2005, 7(Suppl 1):S3-S12.

117. Waxman SG, Dib-Hajj S: Erythermalgia: molecular basis for an inherited pain syndrome. Trends Mol Med 2005, 11:555-562.

118. Gould HJ 3rd, England JD, Soignier RD, Nolan P, Minor LD, Liu ZP, Levinson SR, Paul D: Ibuprofen blocks changes in NaV1.7 and 1.8 sodium currents associated with complete Freunds adjuvant induced inflammation in rat. Pain 2004, 5:270-280.

119. Araujo MC, Sinnott CJ, Strichartz GR: Multiple phases of relief from experimental mechanical allodynia by systemic lidocaine: responses to early and late infusions. Pain 2003, 103: 21-29.

120. Kastrup J, Petersen P, Dejgard A, Angelo FR: Intravenous lidocaine infusion: a new treatment of chronic painful diabetic neuropathy. Pain 1987, 28:69-75.

121. Okuse K, Malik-Hall M, Baker MD, Poon W-YL, Chao MV, Wood JN: Annexin II light chain regulates sensory neurone-specific sodium channel expression. Nature 2002, 417:653-656.

122. Rush AM, Craner MJ, Kageyama T, Dib-Haj SD, Waxman SG: Contactin regulates the current density and axonal expres- 
sion of tetrodotoxin-resistant but not tetrodotoxin- sensitive sodium channels in DRG neurons. Eur J Neurosci 2005, 22:3949.

123. Yaksh TL: Calcium channels as therapeutic targets in neuropathic pain. Pain 2006, 7(Suppl 1):S13-S30.

124. Altier C, Khosravani $H$, Evans RM, Hameed S, Peloquin JB, Vartian BA, Chen L, Beedle AM, Ferguson SS, Mezghrani A, et al:: ORL-1 receptor mediated internalization of $\mathrm{N}$-type calcium channels. Nat Neurosci 2005, 9:31-40.

125. Kim C, Jun K, Lee T, Kim SS, McEnery MW, Chin H, Kim HL, Park JM, Kim DK, Jung SJ, Kim J, Shin HS. Altered nociceptive response in mice deficient in the $\alpha(1 \mathrm{~B})$ subunit of the voltagedependent calcium channel. Mol Cell Neurosci 2001, 18:235245

126. Saegusa $H$, Kurihara $T$, Zong $S$, Kazuno A, Matsuda $Y$, Nonaka $T$, Han W, Toriyama $H$, Tanabe T: Suppression of inflammation and neuropathic pain symptoms in mice lacking the N-type Ca2+ channel. EMBO J 2001, 20:2349-2356.

127. Xiao WH, Bennett GJ: Synthetic omega-conopeptides applied to the site of nerve injury suppress neuropathic pains in rats. $J$ Pharmacol Exp Ther 1995, 274:666-672.

128. Snutch TP: Targeting chronic and neuropathic pain: the N-type calcium channel comes of age. NeuroRx 2005, 2:662-670.

129. Ikeda H, Heinke B, Ruscheweyh R, Sandkuhler J: Synaptic plasticity in spinal lamina 1 projection neurons that mediate hyperalgesia. Science 2003, 299:1237-1240

130. Matthews EA, Dickenson AH: Effects of spinally delivered Nand P-type voltage dependent calacium channel antagonists on dorsal horn neuronal responses in a rat model of neuropathy. Eur J Pharmacol 2001, 415:141-149.

131. Flatters SJ, Bennett GJ: Ethosuximaide reverses paclitaxel and vincristine-induced painful peripheral neuropathy. Pain 2004, 109:150-161

132. Lu Y, Westlund KN: Gabapentin attenuates nociceptive behaviours in an acute arthritis model in rats. J Pharmacol Exp Ther 1999, 290:214-219.

133. Luo ZD, Calcutt NA, Higuera ES, Valder CR, Song YH, Svensson $\mathrm{Cl}$, Myers RR: Injury type-specific calcium channel alpha (2) delta-1 subunit up-regulation in rat neuropathic pain models correlates with antiallodynic effects of gabapentin. J Pharmacol Exp Ther 2002, 303:1199-1205.

134. Jaffe M, et al.: Post-hoc results show beneficial effects of pregabalin in patients with osteoarthritis of the hip. Arthritis Rheum 2000, 43:Supplement Abs 1621.

135. Sah DWY, Ossipov MH, Porecca F: Neurotrophic factors as novel therapeutics for neuropathic pain. Nat Rev Drug Discov 2003; 2:460-472.

136. Zweifel LS, Kuruvilla R, Ginty DD: Functions and mechanisms of retrograde neurotrophin signaling. Nat Rev Neurosci 2005, 6:615-625.

137. Lu B, Pang PT, Woo NH: The Yin and Yang of neurotrophin action. Nature Rev Neurosci 2005, 6:603-614.

138. Ro LS, Chen ST, Tang LM, Jacobs JM: Effect of NGF and antiNGF on neuropathic pain in rats following chronic constriction injury of the sciatic nerve. Pain 1999, 79:265-274.

139. Theodosiou M, Rush RA, Zhou XF, Hu D, Walker JS, Tracey DJ: Hyperalgesia due to nerve damage: role of nerve growth factor. Pain 1999, 81:245-255.

140. Hefti FF, Rosenthal A, Walicka PA, Wyatt S, Vergara G, Shelton DL, Davis AM: Novel class of pain drug based on antagonism of NGF. Trends Pharmacol Sci 2005, 27:85-91.

141. Ji RR, Samad TA, Jin SX, Schmoll R, Woolf CJ: P38 MAPK activation by NGF in primary sensory neurons after inflammation increases TRPV1 levels and maintains heat hyperalgesia. Neuron 2002, 36:57-68.

142. Fjell J, Cummings TR, Fried K, Black JA, Waxman SG: In vivo NGF deprivation reduces SNS expression and TTX-R sodium currents in IB4-negative DRG neurons. J Neurophysiol 1999, 81:803-810.

143. Mamet J, Lazdunski M, Voilley N: How nerve growth factor drives physiological and inflammatory expression of acidsensing ion channels 3 in sensory neurons. J Biol Chem 2003, 278:48907-48913.

144. Petersen M, Segond von Banchet G, Heppelmann B, Koltzenburg $M$ : Nerve growth factor regulates the expression of bradykinin binding sites on adult sensory neurons via the neurotrophin receptor p75. Neuroscience 1998, 83:161-168.
145. Ramer MS, Bradbury EJ, McMahon SB: Nerve growth factor induces P2X(3) expression in sensory neurons. J Neurochem 2001, 77:864-875.

146. Oddiah D, Anand P, McMahon SB, Rattray M: Rapid increase of NGF, BDNF and NT3 mRNAs in inflamed bladder. NeuroReport 1998, 9:603-608.

147. Miller LJ, Fischer KA, Goralnick SJ, Litt M, Burleson JA, Albertsen $P$, Kreutzer DL: Nerve growth factor and chronic prostatis/chronic pelvic pain syndrome. Urology 2002, 59: 603-608.

148. Aloe L, Tuveri MA, Carcassi U, Levi-Montalcini R: Nerve growth factor in the synovial fluid of patients with chronic arthritis. Arthritis Rheum 1992, 35:3351-3355.

149. Halliday DA, Zettler C, Rush RA, Scicchitano R, McNeil JD: Elevated growth factor levels in the synovial fluid of patients with inflammatory joint disease. Neurochem Res 1998, 23:919-922.

150. Sarchielli $P$, Alberti A, Floridi A, Gallai V: Levels of nerve growth factor in cerebrospinal fluid of chronic headache patients. Neurology 2001, 57:132-134.

151. Andreev N, Dimitrieva N, Kolzenburg M, McMahon SB: Peripheral administration of nerve growth factor in the adult rat produces a thermal hyperalgesia that requires the presence of sympathetic post-ganglionic neurones. Pain 1995, 63:109115.

152. Apfel SC: Nerve growth factor for the treatment of diabetic neuropathy: what went wrong, what went right, and what does the future hold? Int Rev Neurobiol 2002, 50:393-413.

153. Sah DWY, Ossipov MH, Porecca F: Neurotrophic factors as novel therapeutics for neuropathic pain. Nat Rev Drug Discov 2003, 2:460-472.

154. Owolabi JB, Rizkalla G, Tehim A, Ross GM, Riopelle RJ, Kamboj R, Ossipov M, Bianm D, Wegert S, Porreca F, Lee DK: Characterization of antiallodynic actions ALE-0540, a novel nerve growth factor receptor antagonist, in the rat. J Pharmacol Exp Ther 1999, 289:1271-1276.

155. Colquhoun A, Lawrance GM, Shamovsky IL, Riopelle RJ, Ross GM: Differential activity of the nerve growth factor (NGF) antagonist PD90780 [7-benzoylamino)-4,9-dihydro-4methyl8-oxo-pyrazolo-[5,1-b]-quinazoline-2-carboxylic acid] suggest altered NGF-p75NTR interactions in the presence of trkA. $J$ Pharmacol Exp Ther 2004, 310:505-511.

156. Lane N, Webster L, Shiao-ping Lu, Gray M, Hefti F, Walicke P: RN624 (anti-NGF) improves pain and function in subjects with moderate knee osteoarthritis: a phase i study. Arthritis Rheum 2005, 52:S461.

157. Coull JA, Beggs S, Boudreau D, Boivin D, Tsuda M, Inoue $K$, Gravel C, Salter MW, De Koninck Y: BDNF from microglia causes the shift in neuronal anion gradient underlying neuropathic pain. Nature 2005, 438:1017-1021.

158. Kerr BJ, Bradbury EJ, Bennett DL, Trivedi PM, Dassan P, French J, Shelton DB, McMahon SB, Thompson SW: Brain derived neurotrophic factor modulates nociceptive sensory neurone input and NMDA-evoked responses in the rat spinal cord. $J \mathrm{Neu}^{-}$ rosci 1999, 19:5136-5149.

159. Deng YS, Zhong JH, Zhou XF: Effects of endogenous neurotrophin on sympathetic sprouting in the dorsal root ganglia and allodynia following spinal nerve injury. Exp Neurol 2000, 164:344-350.

160. Nutt JG, Burchiel KJ, Comella CL, Jankovic J, Lang AE, Laws ER Jr, Lozano AM, Penn RD, Simpson RK Jr, Stacy M, Wooten GF: ICV GDNF Study Group. Implanted intracerebroventricular. Glial cell line-derived neurotrophic factor. Randomized, double-blind trial of glial cell line-derived neurotrophic factor (GDNF) in PD. Neurology 2003, 60:69-73.

161. Welch MJ, Purkiss JR, Foster KA: Sensitivity of embryonic rat dorsal root ganglia neurons to Clostridium botulinum neurotoxins. Toxicon 2000, 38:245-258.

162. Mense S: Neurobiological basis for the use of botulinum toxin in pain therapy. $J$ Neurol 2004, 251(Suppl 1):11-17.

163. Mahowald ML, Singh JA, Dykstra D: Long term effects of intraarticular botulinum toxin A for refractory joint pain. Neurotox Res 2006, 9:179-188.

164. Apostolidis A, Popat R, Yiangou Y, Cockyne D, Ford ABDW, Davis JB, Dasgupta P, Fowler CJ, Anand P: Decreased sensory receptors P2X (3) and TRPV1 in suburothelial nerve fibers following intradetrusor injection of botulinum toxin for human detrusor overactivity. J Uro/ 2005, 174:977-982. 
165. D'Amour FE, Smith DL: A method for determining loss of pain sensation. J Pharmacol Exp Ther 1941, 72:74-79.

166. Woolfe G, MacDonald AD: The evaluation of the analgesic action of pethidine hydrochloride (Demerol). J Pharmacol Exp Ther 1944, 80:300-307.

167. Le Bars D, Gozariu M, Cadden SW: Animal models of nociception. Pharmacol Rev 2001, 53:597-652.

168. Felson DT, Chaisson CE, Hill CL, Totterman SM, Gale ME, Skinner KM, Kazis L, Gale DR: The association of bone marrow lesions with pain in knee osteoarthritis. Ann Intern Med 1002, 134:541-549.

169. Hill CL, Gale DG, Chaisson CE, Skinner K, Kazis L, Gale ME, Felson DT: Knee effusions, popliteal cysts and synovial thickening: association with knee pain in osteoarthritis. J Rheumatol 2001, 28:1330-1337.

170. Wluka AE, Wolfe R, Stuckey R, Cicuttini FM. How does tibial cartilage volume relate to symptoms in subjects with knee osteoarthritis? Ann Rheum Dis 2004, 63:264-268.

171. Van Der Kraan OM, Vitters EL, van de Putte LBA, van den Berg WB: Development of osteoarthritic lesions in mice by "metabolic" and "mechanical" alterations in the knee joints. Am J Pathol 1989, 135:1001-1014.

172. Clarke KA, Heitmeyer SA, Smith AG, Taiwo YO: Gait analysis in a rat model of osteoarthritis. Physiol Behav 1997, 62:951-954.

173. Ivanavicius SP, Ball AD, Heapy CG, Westwood FR, Murray F, Read SJ: Structural pathology in a rodent model of osteoarthritis is associated with neuropathic pain: Increased expression of ATF-3 and pharmacological characterization. Pain 2007, in press.

174. Bove SE, Calcaterra SL, Brooker RM, Huber CM, Guzman RE, Juneau PL, Schrier DJ, Kilgore KS: Weight bearing as a measure of disease progression and efficacy of anti-inflammatory compounds in a model of monosodium iodoacetate-induced osteoarthritis. Osteoarthritis Cartilage 2003, 11:821-830.

175. Fernihough J, Gentry C, Malcangio M, Fox A, Rediske J, Pellas T, Kidd B, Bevan S, Winter J: Pain releated behaviour in two model of osteoarthritis in the rat knee. Pain 2004, 112:83-93.

176. Pomonis JDM, Boulet JM, Gottshall SL, Phillips S, Rani S, Bunton T, Walker K: Development and pharmacological characterization of a rat model of osteoarthritis pain. Pain 2005, 114:339346. 